\title{
Analysis of IGF-1 gene in ayam ketawa (Gallus gallus domesticus) with dangdut and slow type vocal characteristics
}

\author{
ABINAWANTO ${ }^{1, \bullet}$, ALFI SOPHIAN ${ }^{1,2}$, RETNO LESTARI $^{1}$, ANOM BOWOLAKSONO ${ }^{1}$, \\ PIPIH SUNINGSIH EFENDI ${ }^{3}$, RUDI AFNAN ${ }^{3}$ \\ ${ }^{1}$ Biology Postdoctoral Program, Faculty of Mathematics and Natural Sciences, Universitas Indonesia. Jl. Lingkar UI, E Building UI Campus, Depok \\ 16242, West Java, Indonesia. Tel.: +62-21-7270163, Fax.: +62-21-78829010, ^email: abinawanto.ms@ sci.ui.ac.id \\ ${ }^{2}$ Biology Testing Laboratory, National Agency of Drug and Food Control (NADFC). Gorontalo City 96100, Gorontalo, Indonesia. \\ ${ }^{3}$ Genetics Laboratory, Faculty of Animal Husbandry, Institut Pertanian Bogor. J1. Raya Dramaga, Bogor 16680, West Java, Indonesia
}

Manuscript received: 14 June 2019. Revision accepted: 28 June 2019

\begin{abstract}
Abinawanto, Sophian A, Lestari R, Bowolaksono A, Efendi PS, Afnan R. 2019. Analysis of IGF-1 gene in ayam ketawa (Gallus gallus domesticus) with dangdut and slow type vocal characteristics. Biodiversitas 20: 2004-2010. Insulin-like growth factor 1 (IGF-1) is defined as an essential gene for growth. Therefore, this research aims to identify the polymorphism of the IGF-1 gene from ayam ketawa with the dangdut and slow type vocal characteristics. Twenty male chickens were selected as an animal model. The sample consisted of 10 chickens with the dangdut type and 10 chickens with the slow type. The chickens were all obtained from five areas of the Pinrang district. The RFLP and HRM methods were selected to be used in this research. Results showed that the IGF-1 gene was 622 bp in length, while polymorphism analysis showed that the dangdut and slow type are homozygotic. The unrestricted DNA fragment indicated it after reaction of the restriction enzyme Pst 1 . Moreover, it confirmed that ayam ketawa with the dangdut or slow type had a similar sequence.
\end{abstract}

Keywords: ayam ketawa, HRM, IGF-1, polymorphism, RFLP

\section{INTRODUCTION}

Restriction fragment length polymorphism (RFLP) and high-resolution melting (HRM) are methods commonly used for polymorphism analysis. These are fast and straightforward techniques with high accuracy as compared to DNA sequencing methods (Krypuy et al. 2006; Kawada et al. 2008). RFLP is a general technique for identifying the variation of nucleotides within a DNA fragment. The analysis is conducted on the DNA fragment through an amplification process. The fragment was restricted and then confirmed by electrophoresis (Nakashima et al. 2003). HRM analysis, on the other hand, is a method developed to precisely identify the genetic variation and mutation within a DNA sequence without employing a sequencing technique.

Moreover, it could be used to determine the genetic variation in a population (Kapa Biosystem 2007). HRM is highly utilized for single nucleotide polymorphism (SNP) genotyping, DNA methylation analysis, DNA fingerprints, species identification, and DNA mutation (Corbett Research 2006). The DNA characterization by HRM is determined based on several characteristics - for instance, length of the DNA sequence, guanine and cytosine base content, and DNA complementary sequence. The HRM method has high sensitivity and is able to detect the change of a single nucleotide base within a DNA sequence. Therefore, the minor mutation known as a dot mutation will produce different patterns of HRM results (Wittwer 2009).
Insulin-like growth factor-1 (IGF-1) is a protein with an insulin-like structure, and its main functions include proliferation, differentiation, and metabolism in myogenic cells (Duclos 2005). According to Curi et al. (2005) and Tirapegui (1999), IGF-1 has an essential function for muscle and bone development. The gene has a role similar to insulin, but it is slightly better at inducing growth (Jameson 2010). Gasparino et al. (2013) stated that IGF-1 induces the cell division process, bone development, and protein synthesis. Moreover, it also has the function of repairing the nervous system, brain, heart, and others by inducing organ synthesis (Mangiola et al. 2014).

IGF-1 has a role in supporting the growth of somatic cells, fibroblasts, muscle, and bone (Abbasi and Kazemi 2011). Therefore, this gene is also involved in chicken growth. It consists of 70 amino acids (Giachetto et al. 2004). As mentioned by Smith et al. (2000), a chicken's growth hormone is coded by the $50 \mathrm{~kb}$ gene located in chromosome 1, which is next to the centromere (Smith et al. 2000). The IGF-1 in chicken is composed of seven areas that contain a repeated element. Each element consists of four exons and three introns, at more than $50 \mathrm{~kb}$ in size (Laron 2001).

Based on the work of Nagaraja et al. (2000) and Sco et al. (2001), the single nucleotide polymorphism within the region of IGF-I in chicken can be detected by PCR-RFLP with restriction enzyme Pst 1 . Amills et al. (2003) reported that the SNP method could depict the variation of IGF-1 within a population. Previous research about polymorphism in chickens had been conducted on the penedesenca black 
chicken (Amills et al. 2003), the broiler chicken (Hassani et al. 2015), and the Egyptian chicken (Gouda and Essawy 2010). Identification considered the relation of genetic variation and chicken weight. However, studies of the connection between the polymorphism of IGF-1 and the morphometric characteristics of the vocal cords in chickens is still limited. Therefore, we have researched the variation of IGF-1 and vocal cord morphometric features in chickens with the dangdut or slow type. Research about polymorphism to identify the genetic modification of ayam ketawa is essential since the results of the study could be used as the basis for conservation of genetic variation of chickens originating from Indonesia.

\section{MATERIALS AND METHODS}

\section{Place and time}

The research was conducted from January 2018 to July 2018. Molecular biology analysis was conducted at the Microbiology Laboratory, Balai Pengawas Obat dan Makanan (BPOM) in Gorontalo, and the Molecular Laboratory of PT. Genecraf. Macrogen did the sequencing analysis.

\section{Materials}

The tools used in this research were Qiaqube automatic extraction [Qiagen], PCR machine [Sensquest Lab Cyccle], RT-PCR 5 Plex HRM [Qiagen], QIAxcel electrophoresis [Qiagen], micro pipette 0.1-10 $\mu \mathrm{L}$ [Eppendorf], micro pipette $0-200 \mu \mathrm{L}$ [Eppendorf], micro pipette 100-1000 $\mu \mathrm{L}$ [Eppendorf], vortex [Genie-2], centrifuge [Thermo], tube for micro centrifuge [Eppendorf], test tube rack [Eppendorf], and PCR cabinet [Biosan].

The blood sample was approximately $200 \mu \mathrm{L}$, and a DNA isolation kit QIAamp of DNA Blood Mini Kit (Qiagen), PCR kit, and RT-PCR type of HRM (Qiagen) were used.

\section{Procedures}

An overview of the methodology in this research is as presented in Figure 1.

\section{Animal model}

Twenty male chickens aged 12 months old were the animal model in this research. This sample consisted of 10 chickens with the dangdut type vocal characteristics and 10 chickens with the slow type. The chickens were all randomly obtained from various areas of the Pinrang district, such as Kanie, Bullo, Macege, Rappang, and Sidendreng. Two native chickens, male and female, were selected as a control. Both chickens were selected using purposive sampling.

\section{Blood sample}

A blood sample was isolated from the brachial artery and placed into a tube containing EDTA to prevent blood coagulation. The blood sample was kept $-20^{\circ} \mathrm{C}$.

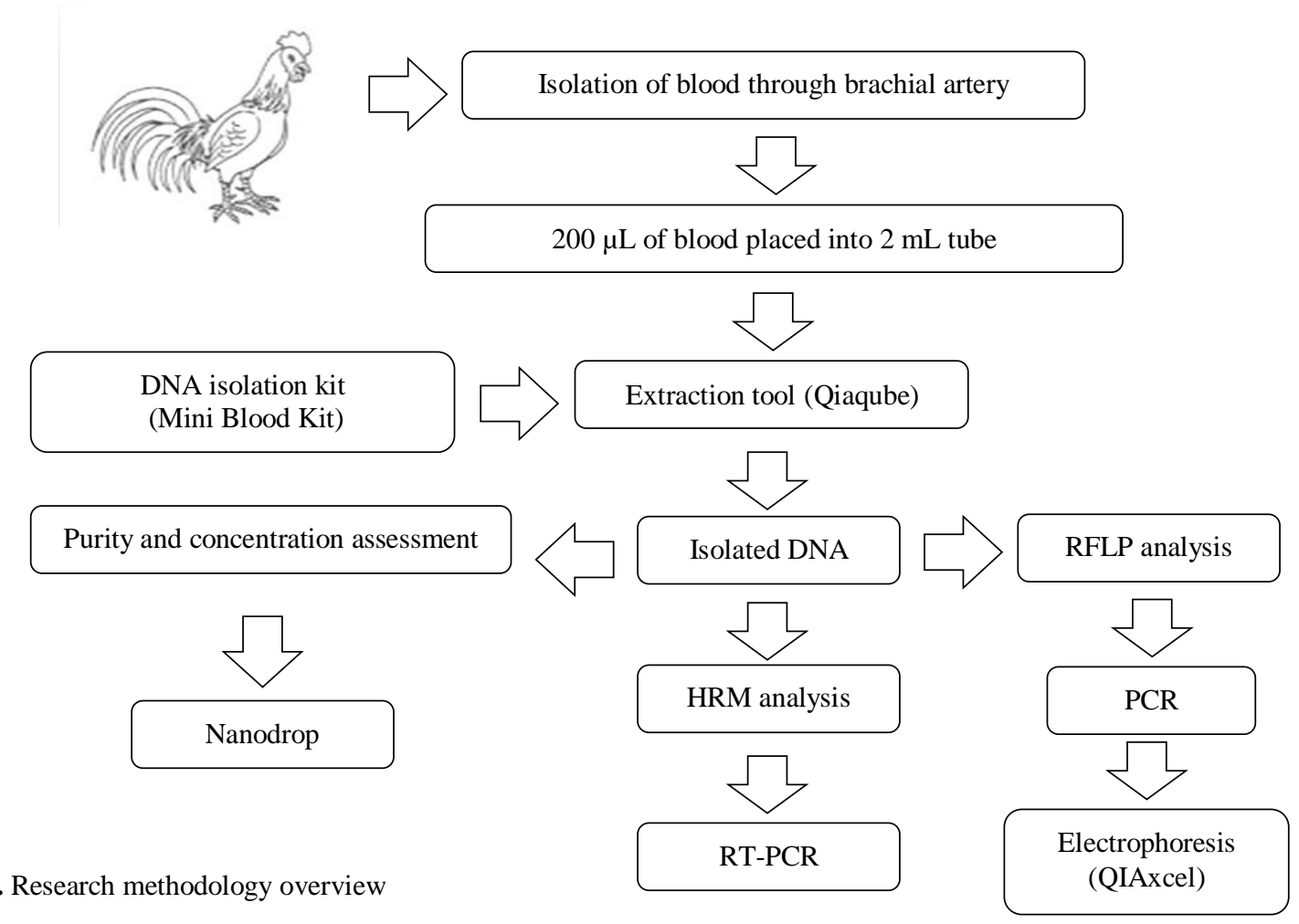

Figure 1. Research methodology overview 


\section{DNA extraction}

DNA isolation is commonly performed using the phenol-chloroform extraction method (Sambrook et al. 1989). Blood extraction was conducted using a QIAamp DNA Blood Mini Kit (Qiagen). The blood sample of approximately $200 \mu \mathrm{L}$ was placed into a microcentrifuge tube containing $20 \mu \mathrm{L}$ of proteinase $\mathrm{K}$ and then mixed. To the mixture was added by $200 \mu \mathrm{L}$ of buffer AL, which was then homogenized by using a vortex for 15 seconds. Next, it was spun down and incubated at $56 \mathrm{oC}$ for 10 minutes.

The mixture was added by $200 \mu \mathrm{L}$ of ethanol (96$100 \%)$, and this was homogenized for 15 seconds. The mixture sample was then placed into a microcentrifuge tube with a spin column connected to the collection tube, and it was centrifuged at $8,000 \mathrm{rpm}$ at $25{ }^{\circ} \mathrm{C}$ for 1 minute. The obtained filtrate in the collection tube was removed, and the spin column was then placed back into the collection tube.

About $500 \mu \mathrm{L}$ of buffer AW1 was added to the spin column and then centrifuged at $8,000 \mathrm{rpm}$ at $25{ }^{\circ} \mathrm{C}$ for 1 minute. Similarly to the previous technique, the filtrate was removed, and the spin column was put into the new collection tube. Furthermore, $500 \mu \mathrm{L}$ of buffer AW2 was added and centrifuged again at $14,000 \mathrm{rpm}$ at room temperature for 3 minutes. The obtained filtrate was eliminated, and the spin column was set back into the microcentrifuge tube. Buffer $\mathrm{AE}$ of about $200 \mu \mathrm{L}$ was added and it was then incubated for 1 minute at room temperature. It was then centrifuged at $8,000 \mathrm{rpm}$ for 1 minute. The obtained solution was then underwent further analysis by nanodrop due to the purity and concentration analysis.

\section{RFLP analysis}

RFLP analysis was conducted as per previous research by Mu'in et al. (2009). An IGF-1 primer with a length of $621 \mathrm{bp}$ was used for this research. In detail, the sequence of the IGF-1 primer was as follows:

IGF-1F: 5'-GAC-TAT-ACA-GAA-AGA-ACC-CAC-3' IGF-1R: 5'-TAT-CAC-TCA-AGT-GGC-TCA-AGT-3'.

The PCR program was adjusted with an initial denaturation stage at $94 \mathrm{oC}$ for 5 minutes, followed by a further process of 35 cycles. In brief, it consisted of a denaturation stage at $94 \mathrm{oC}$ for 45 seconds, an annealing stage at $55 \mathrm{oC}$ for 90 seconds, an extension stage at $72 \mathrm{oC}$ for 60 seconds, and a final extension stage at $72 \mathrm{oC}$ for 10 minutes. The PCR result was confirmed using an automatic electrophoresis QIAxcel (Qiagen).

The PCR result with the current molecule weight was restricted at $37 \mathrm{oC}$ for 16 hours by using the restriction enzyme Pst1. The restriction result was then further analyzed by automatic electrophoresis QIAxcel (Qiagen).

\section{HRM analysis}

HRM analysis was conducted using Real Time-PCR Rotor-Gene Q 5plex HRM and supported by reagent Typeit HRM PCR Kit (Qiagen). The selected program was adjusted on the PCR machine to obtain the optimum result. PCR was conducted for 45 cycles. The initiation stage was set at $95^{\circ} \mathrm{C}$ for 5 minutes, the denaturation stage was at $95^{\circ} \mathrm{C}$ for 10 seconds, the annealing stage was at $55^{\circ} \mathrm{C}$ for 30 seconds, and then polymerization was at $72^{\circ} \mathrm{C}$ for 10 seconds and the post-PCR stage was at $95^{\circ} \mathrm{C}$ for 2 seconds. After that, it continued into melting DNA (HRM) at 65-95 ${ }^{\circ} \mathrm{C}$, with a slight temperature increase of $0.1{ }^{\circ} \mathrm{C} /$ second.

\section{Validation assessment}

The SNP was analyzed by PCR-RFLP and RT-PCR HRM and underwent validation assessment using sequencing provided by Macrogen. MEGA7 was used to analyze the data.

\section{RESULTS AND DISCUSSION}

\section{Purity and concentration assessment of DNA}

The purity and concentration assessment of DNA was analyzed using nanodrop. Ayam ketawa with the dangdut vocal characteristics exhibited an average DNA concentration of about $64,58(\mathrm{ng} / \mathrm{ul})$, with a purity score of 1,93. The DNA concentration of ayam ketawa with the slow type was $85,97(\mathrm{ng} / \mu \mathrm{L})$, with a purity of about 1.92 (Table 1).

Based on the results of the purity and concentration assessment, it can be concluded that the DNA extraction is in excellent condition. As mentioned in the previous result, proper DNA extraction is defined by a purity score within the range of 1.8-2 and with a concentration of above 20 (ng/ $\mu \mathrm{L}$ ) (Kirby 1990; Artama et al. 1992; Muladno 2002). Therefore, this isolated DNA is good enough to be subjected to further analysis such as PCR-RFLP or RTPCR.

\section{PCR analysis}

The amplification result by PCR showed that the IGF-1 gene of ayam ketawa is 632 bp in length (Figure 2). It is similar to previous results which showed that the IGF-1 gene in chicken is $621 \mathrm{bp}$ in length and located at the '5region.

However, there was a different amplification result for the IGF-1 gene from domestic chicken. The local chicken from Azerbaijan (Babayi et al. 2014) and the broiler chicken (Kadlec et al. 2011) had an IGF-1 gene of 622 bp in length, the domestic chicken from Korea (Kim et al. 2004), Pakistan (Ali et al. 2016), and Iran (Abbasi and Kazemi 2011) had an IGF-1 gene of 621 bp in length. According to those previous results, it is known that the IGF-1 gene has various sizes, thus it proves the presence of polymorphism. The various sizes of chicken also show the further effect of polymorphism in this gene.

The IGF-1 gene is known for supporting the growth process (Kadlec et al. 2011). Because of its essential function for growth, the IGF-1 gene can be used for polymorphism analysis. Therefore, it can be used to identify mutation as a genetic variation within a population (Nagaraja et al. 2000; Amills et al. 2003; Bennett et al. 2009). 


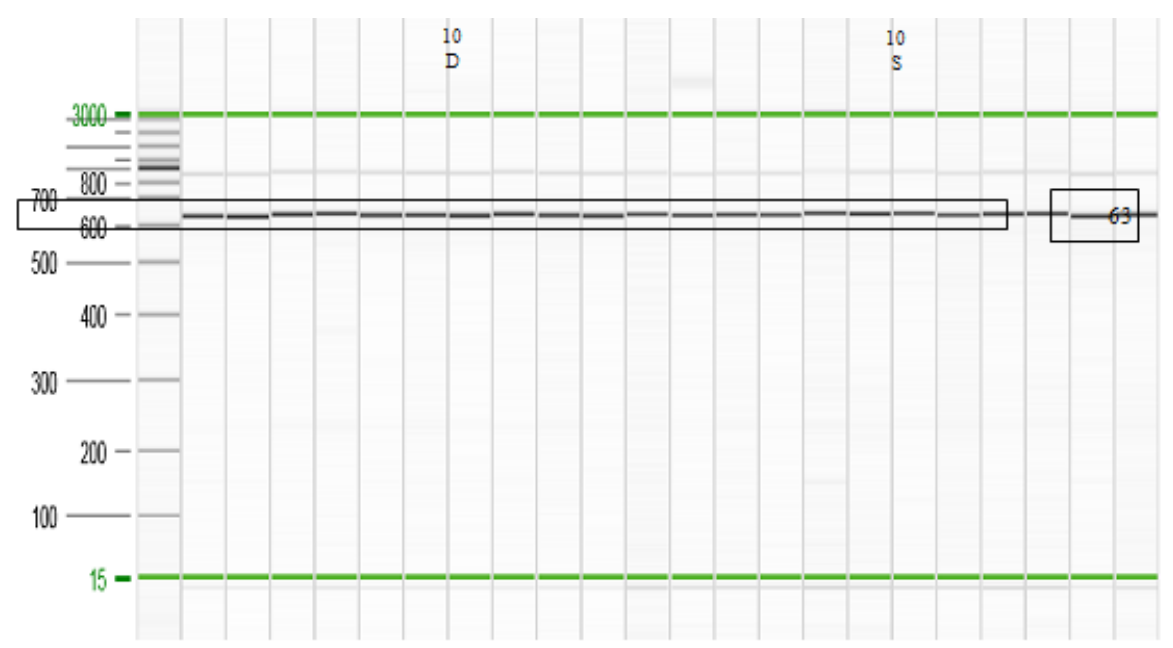

Figure 2. PCR profile of IGF-1 gene: ayam ketawa with dangdut type (D), ayam ketawa with slow type (S), female naïve chicken (K + ) and male naïve chicken $\left(\mathrm{K}^{\curvearrowright}\right)$

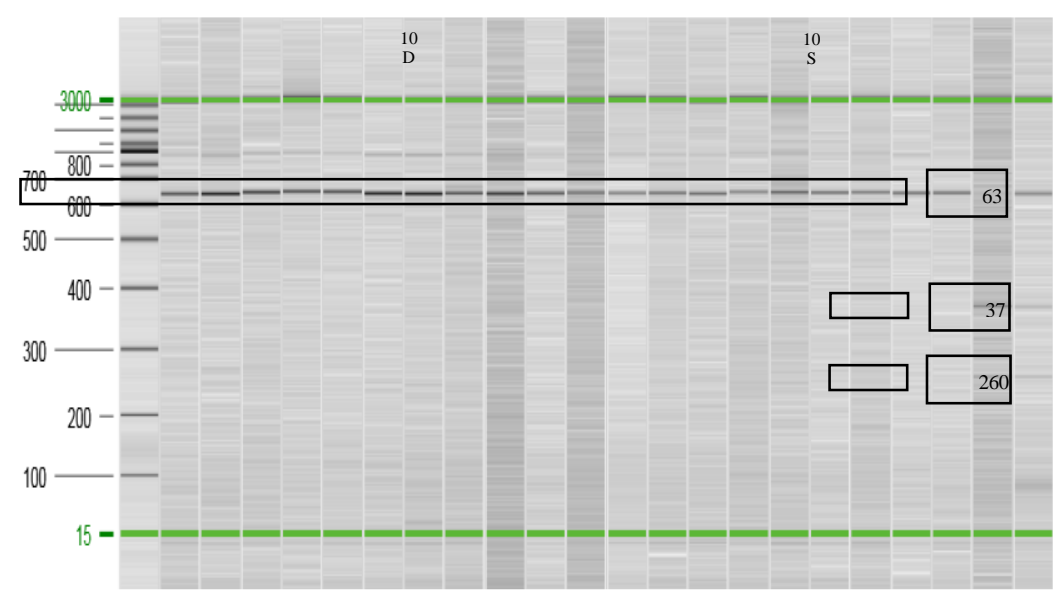

Figure 3. Profile of the IGF-1 gene after being treated with the restriction enzyme Pst 1 for 16 hours: (D) ayam ketawa with dangdut type of length $632 \mathrm{bp},(\mathrm{S})$ ayam ketawa with slow type of length $632 \mathrm{bp}$, (Ko) female naïve chicken at $372 \mathrm{bp}$ and $260 \mathrm{bp}$, (Kふ⿱乛龰) male naïve chicken at $632 \mathrm{bp}, 372 \mathrm{bp}$, and $260 \mathrm{bp}$. Results showed that both ayam ketawa with dangdut and slow type had homozygote alleles, while the naïve chicken showed heterozygote alleles

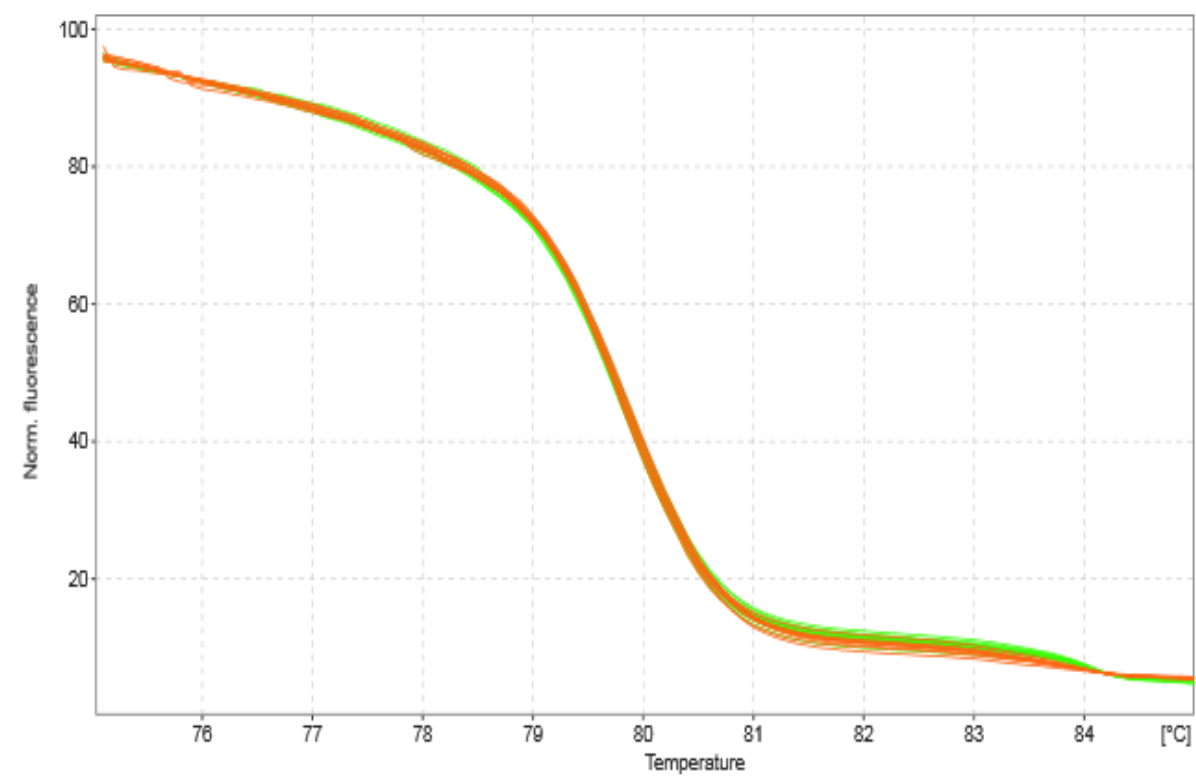

Figure 4. Result of high-resolution melting (HRM) analysis 


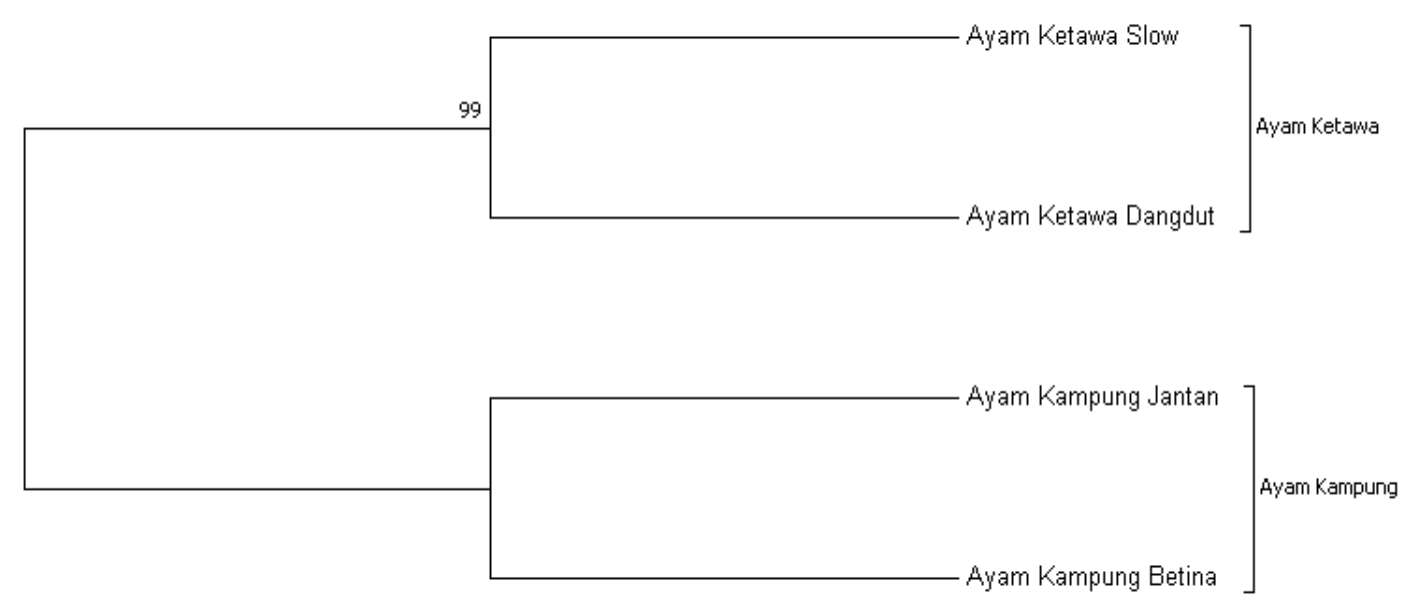

Figure 5. Results of phylogenetic tree analysis

\section{PCR-RFLP analysis}

The results of the PCR-RFLP analysis (Figure 3) showed that both types of ayam ketawa, dangdut and slow type, had homozygote alleles. It is demonstrated by the unrestricted fragment using the restriction enzyme Pst 1 . It is in line with previous results which stated that unrestricted DNA fragments define homozygote alleles (Nagaraja et al. 2000; Kim et al. 2004; Abbasi and Kazemi 2011; Kadlec et al. 2011; Ali et al. 2016). It also supported by Mu'in et al. (2009), who reported that the restriction enzyme would be unable to cut the DNA fragment within homozygote alleles. Therefore, the size of the DNA fragment will not change.

\section{HRM analysis}

The results of the HRM analysis demonstrated that both ayam ketawa with the dangdut and slow type had the same alleles. It was shown within the curve of HRM analysis, which had a line without an intersection (Figure 4).

Based on the result of HRM analysis, the melting point is stated at $77-83^{\circ} \mathrm{C}$, with a $90 \%$ confidence level. Both types of ayam ketawa are settled at the same melting point, determined as homozygote allele. It is supported by Taylor et al. (2010), who stated that HRM analysis is unable to decide on the homozygote and heterozygote alleles if the melting point of the DNA target is linear. Moreover, HRM analysis of SNP could be utilized to determine mutations in the DNA sequence. Therefore, it could construct the homozygote and heterozygote allele patterns (Frazer 2007).

However, several factors render HRM analysis to be incapable of detecting the difference in alleles - for example, a limited DNA template, degradation of the DNA template and inhibitor existence. It should be noted that the heterozygote allele is defined by the intersection present in the pattern (Rouleau 2008).

\section{Genetic distance}

Genetic distance analysis is conducted using the maximum composite likelihood method with MEGA7 software. Results demonstrated that genetic distance between ayam ketawa with the dangdut type and the slow type is 0.031 , while the genetic distance between the ayam ketawa with dangdut type and male and female naïve chickens is 0.055 and 0.050 , respectively. Moreover, the genetic distance between the ayam ketawa with slow type and the male and female naïve chickens was about 0.046 and 0.043 , respectively. The male naïve chicken has a 0.034 score of genetic distance to the female naïve chicken (Table 2).

According to the data, genetic distance analysis showed that ayam ketawa and the naïve chicken had a close relationship. Ayam ketawa with the dangdut type has a closer relation to the slow type than to the male or female naïve chicken. Those relations showed a genetic distance score of about 0.031 . This result is supported by previous results which reported that ayam ketawa with the dangdut and slow types had a genetic distance score of about 0.0110.89 (Abinawanto and Efendi 2017). However, different results showed by Cristiana (pers. comm., 2019) suggested that the genetic distance is between 0.025 and 1.872 .

Table 1. The average results of purity and concentration of isolated DNA

\begin{tabular}{lcc}
\hline \multicolumn{1}{c}{ Type of chicken } & $\begin{array}{c}\text { Concentration } \\
(\mathbf{n g} / \mathbf{u L})\end{array}$ & $\begin{array}{c}\text { Purity } \\
(\mathbf{A 2 6 0 - A 2 8 0 )})\end{array}$ \\
\hline Ayam ketawa dangdut & 64.58 & 1.93 \\
Ayam ketawa slow & 85.97 & 1.92 \\
\hline
\end{tabular}

Table 2. The genetic distance result of ayam ketawa with dangdut and slow type in the phylogenic tree

\begin{tabular}{lcccc}
\hline \multicolumn{1}{c}{ Type of chicken } & $\begin{array}{c}\text { Ketawa } \\
\text { Dangdut }\end{array}$ & $\begin{array}{c}\text { Ketawa } \\
\text { Slow }\end{array}$ & $\begin{array}{c}\text { Male } \\
\text { naïve }\end{array}$ & $\begin{array}{c}\text { Female } \\
\text { naïve }\end{array}$ \\
\hline Ayam ketawa dangdut & & & & \\
Ayam ketawa slow & 0.031 & & & \\
Male naïve & 0.055 & 0.046 & & \\
Female naïve & 0.050 & 0.043 & 0.034 & \\
\hline
\end{tabular}




\section{Phylogenic analysis}

The phylogenic analysis is used to identify the relation between ayam ketawa with the dangdut and slow types. The phylogenic tree is created by the study conducted by MEGA7 with neighbor-join tree and bootstrap methods (Figure 5).

The maximum likelihood method is used to construct the phylogenic tree. This method considers the number of trees, sequence changes or mutations that arise in the sequence variation (Dharmayanti 2012). Figure 5 showed that ayam ketawa with the slow type has a bootstrap score of $99 \%$ compared to the dangdut type. If the bootstrap score is shown to be more than $50 \%$, it can be defined as valid (Gregory 2008).

To conclude, the results of SNP analysis using PCRRFLP or RT-PCR HRM demonstrated that ayam ketawa with the dangdut and slow types have a similar genotype with homozygote $\mathrm{A}$.

\section{ACKNOWLEDGEMENTS}

The authors would like to thank the Universitas Indonesia and Ministry of Research, Technologyn and Higher Education, Republic of Indonesia for financial support by University Competitive Research Grant (PDUPT). We are grateful to the head of Office of Husbandry, South Sulawesi Province and head of Pinrang Regional Office and Gaga Chicken Farmer Association of Pinrang for their courtesy and assistance. We declare that we have no point of interest.

\section{REFERENCES}

Abbasi HA, Kazemi M. 2011. Detection of polymorphism at the insulin like growth factor-I gene in Mazandaran native chicken using polymerase chain reaction-restriction fragment length polymorphism method. Am J Anim Vet Sci 6: 80-83.

Abinawanto A, Effendi PS. 2017. Biodiversity of the Gaga chicken from Pinrang, South Sulawesi, Indonesia based on the bioacoustic analysis and morphometric study. Biodiversitas 18 (4): 1618-1623.

Ali A, Javed K, Ali A, Akram M, Dawood M, Saleem AH. 2016. Polymorphism of insulin-like growth factor-1 gene and its association with growth rate in desi chicken of Pakistan. J Anim Plant Sci 26 (3): 858-861.

Amills M, Jimenez N, Villalba D, Tor M, Molina E, Cubilo D, Marcos C, Francesch A, Sanchez A, Estany J. 2003. Identification of three single nucleotide polymorphisms in the chicken insulin-like growth factor 1 and 2 genes and their associations with growth and feeding traits. Poult Sci 82: 1485-1493.

Artama WT, Agey MW, Donelson JE. 1992. DNA comparisons of Trypanosoma evansi (Indonesia) and Trypanosoma brucei spp. Parasitology 104 (1): 67-74.

Babayi MS, Seyedabadi H, Gorbani A, Zarghami N. 2014. IGF-I Gene polymorphismand its associations with some growth traits in westazerbaijan native chicken using PCR-RFLP techniques. Environ Pharmacol Life Sci 3 (6): 29-32.

Bennett DE, Camacho RJ, Otelea D, Kuritzkes DR, Fleury H, Kiuchi M, Vandamme AM. 2009. Drug resistance mutations for surveillance of transmitted HIV-1 drug-resistance: 2009 update. PloS One 4 (3): e4724. DOI: 10.1371/journal.pone.0004724.

Corbett Research. 2006. High resolution melt assay design and analysis CorProtocol $^{\mathrm{TM}}$ 6000. Corbet life science, Australia.

Curi RA, Oliveira HN, Silveira AC, Lopes CR. 2005. Association between IGF-I, IGF-IR and GHRH gene polymorphism and growth and carcass traits in beef cattle. Livestyle Prod Sci 94: 159-167.
Dharmayanti NLPI. 2012. Molecular phylogenetic: organism taxonomy method based on evolution history. Wartazoa 2 (1): 1-10.

Duclos MJ. 2005. Insulin-like growth factor-I (IGF-1) mRNA levels and chicken muscle growth. J Physiol Pharmacol 56 (Suppl 3): 25-35.

Frazer KA. 2007. A second generation human haplotype map of over 3.1 milion SNPs. Nature 449: 851-861.

Gasparino E, Voltolini DM, Vesco Ap Del, Guimarães SEF, doNascimento CS, Neto ARO. 2013. IGF-I, GHR and UCP mRNA expression in the liver and muscle of high-and low-feed-efficiency laying Japanese quail at different environmental temperatures. Livestyle Sci 157 (1): 339-344.

Giachetto PF, Riedel EC, Gabriel JE, Ferro MIT, Di Mauro SMZ, Macari M, Ferro JA. 2004. Hepatic mRNA expression and plasma levels of insulin-like growth factor-I (IGF-I) in broiler chickens selected for different growth rates. Genet Mol Biol 27 (1): 39-44.

Gouda EM, Essawy GS. 2010. Polymorphism of insulin-like growth factor I gene among chicken breeds in Egypt. Z. Naturforschung 65: 284-288.

Gregory TR. 2008. Understanding evolutionary tress. Evol Educ Outreach 1: $111-137$.

Hassani AS, Hassani DH, Hassan IA. 2015. Association of insulin-like growth factor-1 gene polymorphism at 279 Position of the 5'UTR region with body weight traits in broiler chicken. Asian J Poult Sci 9 (4): 213-222.

Jameson JL. 2010. Harrison's Endocrinology. 2th ed. In Fauci AS, Kasper DL, Longo DL, Braunwald E, Hauser SL, Loscalzo J, Jameson JL (eds). McGraw Hill Medical, Ney York.

Kadlec K, Hosnedlova B, Rehout V, Citek J, Vecerek L, Hanusova L. 2011. Insulin-like growth factor-1 polymorphism and its association with growth and slaughter charasteristics in broiler chickens. J Biol 28 (2): $157-163$.

Kapa Biosystem. 2007. Introduction to high resolution melting analysis. Kapa Biosystem, Boston, MS.

Kawada I, Soejima K, Watanabe H, Nakachi I, Yasuda H, Naoki K, Kawamura M, Eguchi K, Kobayashi K, Ishizaka A. 2008. An alternative method for screening EGFR mutation using RFLP in nonsmall cell lung cancer patients. J Thorac Oncol 3 (10): 1096--1103.

Kim MH, Seo DS, Ko Y. 2004. Relationship between egg productivity and insulin-like growth factor-1 genotypes in Korea native ogol chicken. Poult Sci Assoc 7: 1203-1208.

Kirby LT. 1992. DNA fingerprinting (p. 1). WH Freeman.

Krypuy M, Genni MN, David MT, Matthew C, Alexander D. 2006. High resolution melting analysis for the rapid and sensitive detection of mutations in clinical samples: KRAS codon 12 and 13 mutations in non-small cell lung cancer. BMC Cancer 6: 295. DOI:10.1186/14712407-6-295.

Laron Z. 2001. Insulin-like growth factor 1 (IGF-1): a growth hormone. Mol Pathol 54 (5): 311-316.

Mangiola A, Vigo V, Anile C, DeBonis P, Marziali G, Lofrese G. 2014. Role and importance of IGF-1 in traumatic brain injuries. Biomed Res Intl 2015: 736104. doi: 10.1155/2015/736104.

Mu'in MA, Supriyantono A, Uhi HT. 2009. Polimorfisme gen Insulin-like Growth factor-I dan efeknya terhadap pertumbuhan ayam lokal. J Ilmu Ternak dan Veteriner 14 (4): 289-295. [Indonesian]

Muladno M. 2002. Seputar Teknologi Rekayasa Genetika. Pustaka Wirausaha Muda, Bogor. [Indonesian]

Nagaraja SC, Aggrey SE, Yao J, Zadworny D, Fairfull RW, Kuhnlein U. 2000. Traits association of a genetic marker near the IGF-I gene in egg-laying chickens. J Hered 91: 150-156.

Nakashima H, Mitsuteru A, Yosuke T. 2003. Mutation detection using RT-PCR-RFLP. Methodol Mol Biol 226: 319-322.

Rouleau E, Lefol CD, Bourdon V, Coulet F, Noguchi T, Soubrier F, Che IB, Olschwang S, Sobol H, Lidereau R. 2008. Quantitative PCR highresolution melting (qPCR-HRM) curve analysis, a new approach to simultaneously screen point mutations and large rearrangements: application to MLH1 germline mutations in lynch syndrome. Hum Mutat 1 (1): 1-9.

Sambrook J, Fritsch EF, Maniatis T. 1989. Molecular Cloning: A Laboratory Manual. 2nd ed. Cold Spring Harbor Laboratory Press, New York.

Sco DS, Yun JS, Kang WJ, Jeon GJ, Hong KC, Ko Y. 2001. Association of insulin-like growth factor-I gene polymorhism with serum IGF-I concentration and body weight in Korea native Ogol Chicken. Asian Aust J Anim 14: 915-921. 
Smith J, Paton IR, Bruley CK, Windsor D, Burk D, Ponce de Leon PA, Burt B.W. 2000. Integration of the genetic and physical maps of the chicken macrochromosomes. Anim Genetol 31: 20-27.

Taylor S, Scott R, Kurtz R, Fisher C, Patel V, Bizouam F. 2010. A practical guide to high resolution melt analysis genotyping. Bio-Rad Laboratories Inc. Bulletin 2010, Tech Note 6004, USA.
Tirapegui J. 1999. Effect of insulin-like growth factor-1 (IGF-1) on muscle and bone growth in experimental models. Intl J Food Sci Nutr 50: 231-236.

Wittwer CT. 2009. High-resolution DNA melting analysis: advancements and limitations. Hum Mutat 30 (6): 857-859. 